\title{
CÔTE D'IVOIRE'S 2015 PRESIDENTIAL ELECTION: A Sign of Democratic Progress?
}

\section{Tyson Roberts, Joseph Koné, Stéphane Koffi and Kim Yi Dionne}

Tyson Roberts is a lecturer in Political Science and International Studies at UC Irvine, Irvine, USA email: tyson@cohenroberts.com

Joseph Koné is a training and finance officer at the

Centre for Research and Training on Integrated Development (CREFDI), Abidjan, Côte d'Ivoire email: spiderone0@gmail.com

Stéphane Koffi is a research assistant and webmaster at the Centre for Research and Training on Integrated Development (CREFDI), Abidjan, Côte d'Ivoire email: ksplacide@gmail.com

Kim Yi Dionne is an assistant professor of Government at Smith College,

Northampton, MA, USA

email: kdionne@smith.edu

\begin{abstract}
The 2015 presidential election in Côte d'Ivoire was the first since multiparty elections were introduced in 1990 in which all major parties were able to compete without triggering a civil war. We examine the extent of democratic progress registered by this milestone election, focusing on three democratic qualities of elections: competition, participation, and legitimacy. Whereas competitiveness and participation measures both fell relative to the 2010 election, the 2015 election was contested by all major parties and its results were accepted peacefully, registering a dramatic step forward in the legitimacy of the electoral process and outcome. We support this conclusion with a historical analysis; and by comparing the final 2015 results with parallel vote tabulation for the 2015 election, Afrobarometer survey data from 2014, and a subnational analysis of voter turnout in 2015 relative to 2010.
\end{abstract}

Keywords: competition, participation, legitimacy, democratisation, post-conflict 


\section{INTRODUCTION}

On 25 October 2015, more than 3 million people voted in the presidential election in Côte d'Ivoire. Incumbent president Alassane Ouattara won $83.7 \%$ of the vote, securing his second term in office. The 2015 presidential election was the country's first since its founding father had died in 1993 in which the main opposition was not banned and the result did not trigger a civil war. Observers heralded the election as a success. The broad question we raise in this article is: To what extent can we claim that the 2015 presidential election in Côte d'Ivoire was a sign of democratic progress?

Although the etymology of democracy is clear -'rule by the people' - scholars disagree about how to measure democracy. One characteristic common among definitions of democracy is the role of elections, which give citizens the power to choose their leaders and representatives. Although proponents of single-party regimes argue that only one party is necessary in a democracy, most modern scholars of democracy consider contestation among political parties to be a key component of democracy. Robert Dahl (1975, pp. 3-7), for example, itemised a list of eight required institutional guarantees for democracy, including freedom of expression, right to vote, and free and fair elections. However, he argued that these eight guarantees could be interpreted as constituting two dimensions of democratisation: political competition and inclusiveness. Dahl argued that as a regime increases in inclusiveness and/or increases in the level of public contestation, its level of democracy increases incrementally.

Adam Przeworski and his co-authors (2000, pp. 15-20) focus on contestation as the key ingredient of democracy. Whereas Dahl conceptualises democracy as something that can be measured along a continuum, Przeworski and his coauthors view democracy as dichotomous; either a regime is democratic or it isn't. According to their definition, a regime is democratic if the following conditions are met: the chief executive and the legislature are elected; there is more than one political party; and electoral alternation has occurred, which means an opposition party has defeated the incumbent party and been allowed to take office. Samuel Huntington (1993, p. 267) argued that democracy becomes consolidated after two alternations or turnovers, which would demonstrate that two major political parties were committed to democracy enough to surrender power after losing an election.

Staffan Lindberg (2006, pp. 37-45) agrees with Dahl that democratisation is a continual process, and focuses on three democratic qualities in elections. In addition to Dahl's requirements for political participation and competition, Lindberg includes legitimacy. Especially in new democracies or regimes where the ruling party always wins, elections may be viewed as an empty exercise or may 
trigger violence if voters do not accept the process and the outcome as legitimate. Lindberg argues that elections that are participatory, competitive, and legitimate - even if they do not result in alternation of power - contribute to democratisation by strengthening civil liberties in the society.

In this article, we consider these 'requirements' of democracy to interrogate the claim that the 2015 election provides evidence of democratic progress in Côte d'Ivoire. In particular, we assess to what degree the election was competitive, inclusive, and legitimate relative to previous elections. In short, we find that relative to the 2010 presidential election, which was decided in a close run-off, the 2015 election was not very competitive. However, the 2015 election was far more competitive than most elections in the history of Côte d'Ivoire, which were often uncontested or boycotted by major parties. Similarly, although voter participation in the 2015 election was lower than in 2010, it was higher than in the boycotted presidential elections of 1995 and 2000. (The 2005 election was never held.)

The strongest evidence for greater democratisation in the 2015 election is in the area of legitimacy. Whereas previous elections had legitimacy challenges because of boycotts by major parties or because results were rejected by losers who responded by instigating civil war, the 2015 election was largely peaceful and its results were widely accepted.

Our analysis begins with situating the 2015 election in Côte d'Ivoire's broader political-historical context. To what extent did the 2015 election mark a departure from earlier elections? To answer this question, the following section gives a start-to-end overview of the election based on media reports and official election results. We then summarise the legal framework of election administration in Côte d'Ivoire, assess adherence to the 'rules of the game', and show how inclusion of a range of candidates suggests greater competition in the process - even if this competitiveness was not reflected in the lopsided results. The next section draws largely on observers' reports, which suggest that the 'peacefulness' of the 2015 election trumped all other qualities in branding the election a democratic success. The penultimate section interrogates this success by exploring patterns of turnout and support, and by comparing the official results with a parallel vote tabulation, recent polling data from Afrobarometer, and subnational data on voter turnout in the 2010 election. The final section offers a conclusion to the paper.

\section{POLITICAL-HISTORICAL CONTEXT OF CÔTE D'IVOIRE SINCE INDEPENDENCE}

For the first 30 years of Côte d'Ivoire's independence, the only effective political party was the Parti Démocratique de la Côte d'Ivoire - Rassemblement Démocratique Africain, (PDCI-RDA or Democratic Party of Côte d'Ivoire: African Democratic 
Rally). President Félix Houphouët-Boigny, who founded the PDCI in 1946 during French colonial rule, won six uncontested presidential elections between 1960 and 1985. Participation was fairly high: official voter turnout was often over $99 \%$; more than 2 million voters voted in 1970, and by 1985 over 3 million voters voted for the president. Despite this trend, there was no contestation (African Elections Database 2012).

Economically, Côte d'Ivoire was among Africa's greatest successes (some called it the 'Ivorian miracle') for the first two decades of independence, powered by an expansion of cash crops such as cocoa and coffee. To enable this agricultural expansion, the country was open to immigrants from neighbouring countries such as Burkina Faso, and by the 1970s more than a quarter of the country's population were immigrants (Nugent 2004, p. 180). However, this acceptance of immigrants would not be so warm in later years of economic decline and greater political competition.

In the 1980s, Côte d'Ivoire experienced the same economic downturn and resulting protests and demands for multiparty presidential elections seen elsewhere in Africa. Houphouët-Boigny cleverly agreed to multiparty elections in 1990, before the opposition was able to organise a credible challenge (Nugent 2004, p. 398). The main opposition candidate, Laurent Gbagbo of the Front Populaire Ivoirien (FPI, Ivorian Popular Front) won a mere $18 \%$ of the vote against $82 \%$ for Houphouët-Boigny in the 'less than fair' election (Nugent 2004, p. 398). Following the 1990 election, the regime made it 'virtually impossible for opposition parties to mobilise their supporters, while Gbagbo himself received a two-year prison sentence for incitement in 1992' (Nugent 2004, p. 398).

As Houphouët-Boigny's health declined, Prime Minister Alassane Ouattara assumed more responsibility for running the country. However, when HouphouëtBoigny died in 1993, Henri Konan Bédié, Ouattara's rival and the head of the National Assembly, assumed the presidency. Ouattara resigned his post, left the country to work for the International Monetary Fund and joined a new party, the Rassemblement des Républicains (RDR, Rally of the Republicans). He intended to contest the 1995 presidential election. Bédié saw Ouattara as a potential threat, and before the 1995 election introduced an ultranationalist policy known as Ivoirité in a new electoral code. Ivoirité excluded presidential candidates whose parents were not Ivorian. Bédié's supporters declared that Ouattara was not Ivorian, claiming one of his parents was from Burkina Faso (Whitaker 2005). With Ouattara (RDR) excluded and Gbagbo (FPI) boycotting, Bédié won the 1995 election with $96 \%$ of the vote. Compared with 1990, the 1995 election registered a decline in levels of participation (fewer than 2 million votes were cast) as well as competition and legitimacy. 
By the 1990s, immigrants made up one-third of Côte d'Ivoire's population, mostly in the north, and citizenship played an increasing role in politics. In 1999 General Robert Guéi took power in the country's first coup d'état, with the avowed goal of restoring a sense of national unity and to hold free and fair elections (Nugent 2004, p. 478). Before the 2000 election, a referendum was held for a new constitution, which included the exclusionary rules of the 1995 Electoral Code and other restrictions in Article 35. Ouattara was again excluded, as were Bédié and ten of the other 15 candidates (Whitaker 2005; Piccolino 2014).

With Gbagbo as the only candidate of a major party (FPI) running against General Guéï in the 2000 election, Gbagbo won a majority. Guéi attempted to declare victory until three days of protests forced him to flee the capital (Daddieh 2001; Whitaker 2005). There were calls for fresh elections in which more candidates - including Ouattara - could compete, but Gbagbo maintained Ouattara was a foreigner and said there was no need for new elections (Whitaker 2005). Ivoirité policies continued: Gbagbo's government denied many northerners certificates of nationality if they did not have documents proving their parents were Ivorian, and there were reports of a planned Ivoirité purge of northerners in the military (Bah 2010). This led to the outbreak of war in 2002. Rebel forces attacked Abidjan and other cities, with the stated goals of overthrowing Gbagbo, holding inclusive elections and reinstating disbanded soldiers.

As the war continued, international actors such as the African Union, the Economic Community of West African States (ECOWAS), the United Nations and France mediated a series of peace talks in Accra, Lomé and Paris (Bah 2010). Following the Accra III Agreement in 2004, the FPI-led legislature agreed to pass a law reforming the constitutional requirements for presidential candidacy in preparation for elections in 2005. The legislature also insisted that a constitutional referendum - which has never been held - was necessary to finalise the change (Piccolino 2014). Soon after, however, the military situation deteriorated as government forces inadvertently hit French bases while bombing rebel positions and France retaliated (Bah 2010).

By 2006 war fatigue had set in, Gbagbo's electoral mandate from the 2000 election had expired, and leaders of government and rebel forces realised that military victory was beyond reach. In 2007 Gbagbo invited President Blaise Compaoré of Burkina Faso to facilitate peace talks, resulting in the Ouagadougou Agreement, which ended the war that year and addressed issues such as issuance of national identity cards. Voter registration began in 2008, but elections were postponed in 2009. In early 2010 Gbagbo dissolved the government; he also dissolved the electoral commission, which he accused of voter registration fraud (Bah 2010). This action was followed by popular unrest (Piccolino 2012). After 
commissioning several opinion polls that convinced him he would win, Gbagbo allowed the election to go forward in October 2010.

In the 2010 presidential election, 14 candidates were on the ballot, including leaders of the three major parties: Gbagbo (FPI), Ouattara (RDR) and Bédié (PDCI). In the first round, the top two vote-getters were Gbagbo, the incumbent president; and Ouattara. They received $38 \%$ and $32 \%$ of votes respectively. Former president Bédié came close to achieving a second-round bid with $25 \%$ of the vote.

A second-round runoff election was held on 28 November. On 2 December the Commission Electorale Independante (CEI, Independent Electoral Commission) declared Ouattara - who was endorsed in the second round by Bédié (Bassett 2011) - the fourth Ivorian president. He had reportedly won $54 \%$ of votes cast. The Constitutional Council, whose members are appointed by the president, then invalidated the results from the northern regions (Ouattara's stronghold) and announced that Laurent Gbagbo had been re-elected with $51 \%$ of the vote. Both men swore an oath of office on 4 December 2010.

Ouattara had the support of much of the CEI and the international community, but Gbagbo had the support of the Constitutional Council and the military. Gbagbo refused to step down despite certification by the United Nations Organization in Côte d'Ivoire (ONUCI) of the election results as proclaimed by the CEI. A second civil war broke out for several months, and more than 3000 Ivorians died in the violence between Gbagbo's and Ouattara's supporters (Human Rights Watch 2011).

Gbagbo was arrested on 11 April 2011, and was turned over months later to the International Criminal Court (ICC) to be tried for crimes against humanity committed in the post-election period. Ouattara was declared president on 6 May 2011 by the Constitutional Council. Ouattara's inauguration in the political capital, Yamoussoukro, on 21 May 2011 was attended by many heads of state, including Nicolas Sarkozy, then president of France. Although the outcome had been delayed, the 2010 election was notable because Gbagbo was the first incumbent Ivorian president to be defeated at the ballot box.

The 2010 election was the third consecutive presidential election in Côte d'Ivoire (following 1995 and 2000) that led to significant conflict. When assessing the democratic quality of the 2010 election, it scored well on public contestation and participation: total votes exceeded 4 million for the first time. However, the election suffered from challenges to its legitimacy.

Like beauty, legitimacy is in the eye of the beholder. The CEI, the international community and a major share of Ivorian voters accepted Ouattara's electoral victory, but a substantial portion of the population challenged it. In his work, Lindberg (2006, p. 43) measures legitimacy with three indicators: losers' acceptance of the results; a peaceful campaign and polling day; and electoral regime survival, 
including an absence of coups or civil wars, after the election. The 2010 election failed on all these measures.

In summary, the political-historical context preceding the 2015 election was notably undemocratic. Following the first multiparty presidential election in 1990, in which the country's founding father had won a seventh 5-year term, the main opposition had boycotted the 1995 election because of an electoral code that blocked Ouattara from competing. A military coup preceded the 2000 presidential election, in which Ouattara was again excluded. Civil war followed, which lasted until 2007. The 2005 presidential election was never held. The incumbent - Gbagbo - and Ouattara both claimed victory in the 2010 presidential election, triggering a second civil war. An important feature of the 2015 election, therefore, was its relative calm and the acceptance of the results by losers, which indicates domestic legitimacy.

\section{OVERVIEW OF 2015 PRESIDENTIAL ELECTION IN CÔTE D'IVOIRE}

\section{Candidates}

The Constitutional Council published the final list of presidential candidates on 9 September 2015. After reviewing 33 applications, the Constitutional Council validated ten candidates.

President Ouattara was the candidate of a multiparty coalition called the Rassemblement des Houphouétistes pour la Démocratie et la Paix (RHDP, Rally of the Houphouetistes for Democracy and Peace). The coalition included Ouattara's RDR, PDCI-RDA (which continues to be led by Bédié), Union pour la démocratie et la paix en Côte d /Ivoire (UDPCI, Union for Democracy and Peace in Côte d'Ivoire), Mouvement des forces d'avenir (MFA, Movement of the Forces of the Future) and Union pour la Côte d'Ivoire (UPCI, Union for Côte d'Ivoire).

Running at the age of 73, Ouattara was expected to win re-election because of his strong economic performance (Economist Intelligence Unit 2015a; Africa Confidential 2015a) and his endorsement by his rival, former president Bédié. Under Ouattara, Côte d'Ivoire had experienced what some called a 'second miracle' (Fick 2015). With GDP having grown 9\% annually for the past three years, the country was again one of the fastest-growing on the continent. However, this growth had not trickled down to all citizens, which contributed to dissent among Gbagbo's former supporters. Some in the opposition questioned President Ouattara's eligibility to stand for election (Brice 2015), rehashing doubts from earlier elections about the nationality of his parents (Whitaker 2005).

With Bédié and his PDCI supporting Ouattara, Ouattara's main opponent was Pascal Affi N'Guessan, who was prime minister during Gbagbo's presidency. $\mathrm{N}^{\prime}$ Guessan led the FPI in the absence of the more charismatic Gbagbo, who 
was in prison awaiting trial in the ICC for his role in the civil war after the 2010 election. Between Gbagbo's absence and the lack of a national political presence after having boycotted the 2011 parliamentary and 2013 local elections, the FPI faced a serious disadvantage against the ruling party, even if it had significant popular support (Economist Intelligence Unit 2015a).

N'Guessan represented a multiparty coalition called the Alliance des Forces Démocratique (AFD, Alliance of Democratic Forces), including the FPI and 11 smaller parties (PIT, RPP, AIRD, PRI, NACIP, RDP, UDP, UDTCI, URD, UNG and PCI). N'Guessan and the faction of the FPI that supported him decided that a boycott was not in the party's best interest (Bavier 2015). A hard-line faction of the FPI, however, sought a boycott of the election and tried to remove N'Guessan from his post as leader of the party.

The remaining candidates had little chance of garnering much electoral support. Three members of the Coalition Nationale pour le Changement (CNC) ran, including its leader Charles Konan Banny and Bertin Konan Kouadio, both formerly members of the PDCI party who opposed the party's support of Ouattara. Banny and Bertin Kouadio entered the presidential race as independents (Economist Intelligence Unit 2015a). The third member of the CNC, Mamadou Koulibaly, was the former president of the National Assembly and a member of the Liberté et Démocratie pour la République (LDR, Liberty and Democracy for the Republic) party. Another prominent former member of the PDCI party, Amara Essy -former secretary-general of the Organisation of African Unity - also entered the race as an independent. Former minister Henriette Lagou Adjoua, one of two women among the ten candidates, represented a centrist platform, which included three parties (CPP, PDR and PIA). The other woman, Jacqueline-Claire Kouangoua, ran as an independent, as did two other minor candidates, Siméon Konan Kouadio and Kacou Gnangbo.

\section{The Campaign Period}

Once the Constitutional Council has validated the candidates, the Electoral Code provides for a 14-day campaign period during which candidates have 'equal access to official bodies of press, radio and television ... guaranteed by the National Council of Audiovisual Communication'. Candidates are barred from engaging in campaign activity beyond the official campaign period, including the two days before the election. The official campaign period ran from 9 October to 23 October 2015.

Ouattara enjoyed a significant advantage over his challengers in the campaign, particularly with regard to campaign finance. Government funds finance political parties pursuant to Article 9 of Law No. 2004-494 of 10 September 2004. Presidential candidates enjoy an exceptional grant, the amount of which is entered 
in the budget for the year of a presidential election. In 2015, President Ouattara set aside 100 million francs CFA (approximately \$170 000) for each eligible candidate. One estimate put Ouattara's campaign budget at \$168 million - ten times more than that of his competitors combined (Africa Confidential 2015b). Because they were drawing from meagre budgets, campaigns for opposition candidates relied mostly on campaign staff rather than successful private agencies for communication strategies. This made Ouattara's campaign seem even more polished by comparison (Niakate 2015). Likewise, Ouattara's incumbency status enabled him to travel around the country on 'state visits', which after 9 October were called 'campaign rallies' (Africa Confidential 2015b).

Candidates Koulibaly, Essy and Banny withdrew from the election on October 9, 13 and 23 respectively, claiming conditions for a transparent election had not been met. Koulibaly and other members of the CNC called for a boycott of the election (Human Rights Watch 2015, United Nations Security Council 2015).

Ouattara thus enjoyed significant incumbency advantages, which tend to be overwhelming in dictatorships that hold elections, but are also important in democracies in Africa (Cheeseman 2010). The question for our purposes is whether incumbency advantages in the 2015 Côte d'Ivoire election undermine its democratic progress. One way to assess the democratic quality of the campaign is by studying to what degree Ouattara's economic appeal was based on generation of public goods that benefited the whole nation or distribution of private goods through clientelistic networks that benefited the voter or the voter's group. Wantchekon (2003), among others, finds that incumbents have greater credibility in making clientelist appeals. If Ouattara had won purely through clientelism, this would undermine the democratic legitimacy of the election. However, Ouattara's popularity during the campaign stemmed in part from the economic success of the country, including investment in infrastructure and economic reforms (Fick 2015). This suggests his re-election did not rely predominantly on clientelistic appeals.

Another way to assess the democratic quality of the campaign is by examining to what degree Ouattara and his ruling party used threat or coercion and limits on the opposition's freedom of movement. These are both strategies commonly used in dictatorships that hold elections. We can examine this relative to the ruling party's use of more democratic strategies such as voter mobilisation, party organisation and building electoral majorities (Riedl \& Dickovick 2009).

There were some violent incidents in 2015 , primarily before the campaign period, but on a significantly smaller scale than during the post-electoral crisis of 2010-2011 (Human Rights Watch 2015). In September 2015, after protests instigated by opposition claims that Ouattara's candidacy was invalid according to the constitution, more than 50 opposition members and sympathisers were detained, some without access to legal assistance; and some opposition protests 
were banned (Human Rights Watch 2015). On 22 October, the National Press Council temporarily suspended the publication of three opposition newspapers for undermining cohesion by calling for a boycott of the election (United Nations Security Council 2015). In general, however, there was little violence during the campaign period (United Nations Security Council 2015; Human Rights Watch 2015). The assembly by the PDCI of a broad, multiparty electoral coalition indicates that Ouattara's campaign relied primarily - although perhaps not exclusively - on democratic strategies to win re-election.

\section{Election Results}

Of the 6301189 Ivorians registered to vote, 3330928 (52.9\%) voted in the 2015 presidential election. The CNC coalition claimed turnout was less than $20 \%$, but they offered no evidence supporting that estimate (Fort \& Koffi 2015). To put the 2015 election in comparative context, participation was lower than in 2010, but significantly higher than in the vastly boycotted presidential elections of 1995 and 2000, each of which had recorded fewer than 2 million valid votes.

Ouattara won the election with $83.7 \%$ of the vote. His total vote count, more than 2.6 million votes, was a slight improvement on his performance in 2010, when he had won fewer than 2.5 million votes. The landslide victory was therefore accomplished by lower turnout for his opponents rather than mobilisation of supporters for the incumbent. Ouattara's closest challenger was N'Guessan, who won $9.3 \%$ of the popular vote.

Table 1

2015 presidential election results

\begin{tabular}{|l|l|c|c|}
\hline \multicolumn{1}{|c|}{ Candidate } & \multicolumn{1}{c|}{ Party } & \multicolumn{1}{c|}{ Votes } & Vote Share \\
\hline Alassane Ouattara & RDR (RHDP) & $2,618,229$ & $83.7 \%$ \\
\hline Pascal Affi N'Guessan & FPI & 290,780 & $9.3 \%$ \\
\hline Bertin Konan Kouadio & Independent (CNC) & 121,386 & $3.9 \%$ \\
\hline Henriette Lagou Adjoua & CNRD & 27,759 & $0.9 \%$ \\
\hline Siméon Konan Kouadio & Independent & 22,117 & $0.7 \%$ \\
\hline Kacou Gnangbo & Independent & 18,650 & $0.6 \%$ \\
\hline Jacqueline-Claire Kouangoua & Independent & 12,398 & $0.4 \%$ \\
\hline Charles Konan Banny & Independent (CNC) & 8,667 & $0.3 \%$ \\
\hline Amara Essy & Independent & 6,413 & $0.2 \%$ \\
\hline Mamadou Koulibaly & LDR (CNC) & 3,343 & $0.1 \%$ \\
\hline
\end{tabular}


Table 1 provides a breakdown of the results. Because Ouattara secured more than half the votes cast in the first round, there was no need for a run-off election. When the CEI announced the provisional results on 28 October 2015, N'Guessan, Bertin Kouadio, Siméon Konan and Kouangoua publicly conceded defeat and congratulated President Ouattara on his re-election (United Nations Security Council 2015).

\section{CÔTE D'IVOIRE'S LEGAL ELECTORAL FRAMEWORK AND HOW THE 2015 ELECTION MEASURED UP}

The legitimacy of the 2015 election rests at least in part on whether the government and candidates followed the 'rules of the game'. In this section, we account for how well the 2015 election followed these rules. We evaluate firstly how the Constitutional Council and the CEI carried out their duties in administering the election, and secondly the relevance of voter and candidacy eligibility requirements stipulated in Côte d'Ivoire's constitution for the 2015 election.

\section{Electoral Administration}

From independence until the 1999 coup, elections fell under the Ministry of the Interior's authority, meaning that a government-appointed commission organised all elections. The Supreme Court was responsible for litigating any election-related disputes (Kimou \& Kouyaté 2015). The 1994 Electoral Code, adopted in preparation for the 1995 election, created the Constitutional Council to litigate election disputes. The Constitutional Council, made up of seven members appointed by the president, is also responsible for determining whether candidates are eligible to appear on the ballot and for validating election results.

The Constitutional Council rejected 23 of the 33 applications for candidacy in the 2015 presidential election. The rejected candidates failed to meet certain technical requirements in their application, including document submission or paying the candidacy fee. Media reports we reviewed did not identify major complaints about candidate disqualifications. Most importantly, no major parties or candidates were disqualified; the only major candidate not contesting was Gbagbo, who was in the Hague.

In contrast to elections from independence through 2000, in which major parties or candidates were systematically barred from participating or boycotted because of an expectation of unfairness, the 2015 election was inclusive. It laid the groundwork for a competitive election accepted by most (but not all) major stakeholders as legitimate. The Constitutional Council validated the election results on 31 October. This agreement with the other major electoral institution, the CEI, was in stark contrast to the decision by the Constitutional Court in 2010 
to invalidate the CEI's electoral results. The alignment of these two institutions after the 2015 election contributed to the legitimacy of the electoral outcome.

The 2000 Constitution (Article 32, paragraph 4) states that the organisation and supervision of elections are to be carried out by an independent commission. The CEI - whose members include a representative of the presidency, the legislature and each major political party - is responsible for registering voters, counting votes and announcing provisional results. The CEI was not established until after the 2000 election by Law No. 2001-634, which took effect on 9 October 2001.

The CEI began registering voters for the 2015 election on 1 June 2015. The registration period, scheduled to end on 30 June 2015, was extended at the recommendation of the $\mathrm{CEI}$ for an additional two weeks to facilitate registration of more voters. Plateforme des Organisations de la Société Civile pour l'Observation des Elections en Côte d'Ivoire (POECI), a 14-member non-partisan coalition, was accredited to observe the voter registration process. There was thus pressure on the CEI to increase the inclusiveness and transparency of the process. Ultimately POECI reported a significant number of new eligible voters had not been successfully registered for a variety of reasons, including lack of identification, late start and seasonal rains (Ngotta 2015). POECI did not, however, report a bias towards registering government supporters.

The CEI administered the elections at nearly 20000 polling stations. In general the election was conducted 'smoothly', although implementation was imperfect (POECI 2015a; United Nations Security Council 2015). Nearly half of all polling stations opened late (POECI 2015a), some because of delays in the arrival of electoral materials (United Nations Security Council 2015). Another major challenge to implementation was the failure of some biometric systems for authenticating voters: $40 \%$ of polling stations reported having at least one biometric kit fail at some point on election day (POECI 2015a).

Despite its legal independence, the functional independence of the CEI has been questioned, in part because of its limited financial resources, since 2003 or even earlier (Kimou \& Kouyaté 2015). Koulibaly, CNC member and presidential candidate for the LDR party, argued that '.. our Electoral Commission does not meet any criteria of independence. Neither in functions, financially or organically ...' (Bath 2015). Leaders of the CNC threatened to block the 2015 presidential election unless the government addressed its concerns about security issues and pro-government bias in the electoral commission (Flynn 2015). Some observers saw the CNC's actions as 'an effort by its members to win political prominence ahead of October's election, and possibly cabinet places after the vote' (Flynn 2015). 
In general, although irregularities occurred, there is relatively little evidence that such irregularities were the result of widespread fraud rather than inadequate resources and organisation. Most observers agree they did not materially affect the outcome and therefore the legitimacy of the election, particularly relative to previous elections in Côte d'Ivoire.

\section{Eligibility Requirements}

According to Article 33 of the 2000 Constitution, 'All Ivorian nationals of both sexes 18 years old at least and possessing their civil and political rights' have the right to vote. In the 2000 election, Gbagbo's FPI sought to 'clean' the electoral lists to eliminate foreigners, in a 'controversial process of identification of the population after Gbagbo's election' (Piccolino 2014, p. 55). One can construe as problematic for legitimacy either ignoring or applying rules of exclusion. Ignoring the rule would allow some people to vote who could be challenged by some Ivorians as ineligible, calling into question the election's outcome as legitimate. Applying the rule would disenfranchise voters who would see it as making the election illegitimate. In our review of reports on the election we found no claims that any voter's registration in 2015 was challenged based on Ivoirité.

There are additional requirements for presidential candidacy, as laid out in Article 35 of the Constitution. These include:

- being at least 40 years old and no more than 75;

- being of Ivorian origin, born of father and mother themselves of Ivorian origin;

- having never renounced Ivorian nationality;

- never having had another nationality; and

- residence in Côte d'Ivoire continuously during the five years preceding the date of the elections and a total of ten years of effective presence.

The enforcement of the Ivorian origin clause in Article 35 is problematic because Côte d'Ivoire as a state was not formed until 1960. What does 'Ivorian origin' mean for candidates and their parents who were born before Côte d'Ivoire's independence in 1960? Article 35 'was formulated in terms so vague and broad that it could be invoked to justify the exclusion of almost any candidate' (Piccolino 2014). As discussed earlier, General Guéí's government used Article 35 to exclude many candidates opposing him in the 2000 election, including major figures representing two of Côte d'Ivoire's largest parties.

Following the terms of a peace settlement prior to the 2005 election (which was never held), the National Assembly passed legislation allowing citizens 
with only one Ivorian parent to run for office (Lansford 2015, p. 347). However, Gbagbo's FPI insisted that a constitutional referendum was necessary to finalise this and other changes to the electoral rules proposed in the same legislation (Piccolino 2014). Such a referendum has never been held. Some members of the opposition therefore continued to question Ouattara's eligibility to run for office (Brice 2015).

Since the Constitutional Council did not invoke the Ivorian origin clause in refuting any 2015 candidate applications, one interpretation could be that this election had greater potential for competition than previous elections. Furthermore, citizens supporting candidates previously excluded by the clause might have perceived the 2015 election as more legitimate than previous elections because their candidate was not excluded. On the other hand, citizens supporting candidates who would not have been excluded based on the Ivorian origin clause, and who opposed the election of a candidate whose Ivoirité was called into question, may view the 2015 election as less legitimate.

\section{PEACEFULNESS TRUMPS OTHER ELECTION INDICATORS IN DECLARING SUCCESS}

To our knowledge there are no detailed election observers' reports of the 2015 Ivorian election, so the forthcoming analysis draws primarily on assessments made in interviews or statements published in the media or captured in brief media releases. To be sure, there were many election observers, domestic and international. POECI had the largest group of observers: it reported deploying 1000 domestic observers across the country (POECI 2015a). The African Union and ECOWAS also deployed observers during the 2015 election. ${ }^{1}$ While all these organisations issued media releases characterising their observations, none published long, qualitative analyses of the 2015 election - as was done, for example, for the 2010 election (see e.g. Carter Center 2012). Media mentions and media releases by observers characterised the election as a success owing largely to its peacefulness. In this section we synthesise observers' findings and demonstrate how important 'peacefulness' was to observers.

Although the pre-election period was generally peaceful, there were moments of violence. For example, on 10-11 September 2015 strongholds of the FPI opposition party experienced clashes between security forces and protesters reacting to the Constitutional Council's validation of Ouattara as an eligible candidate. Three people died in the clashes (Economist Intelligence Unit 2015b;

1 We found no evidence that Western observers - such as the European Union Election Observation Mission or the Carter Center - sent election observers to Côte d'Ivoire in 2015. 
United Nations Security Council 2015). Any violence during an election campaign is harmful to the perceived legitimacy of the election. The level of violence was dramatically lower than that experienced in 2010, however, and seems lower than had been expected.

Having had recent experience with violence around previous elections, Ivorians were understandably concerned about violence in 2015. When asked how much they personally feared becoming a victim of political intimidation or violence during election campaigns, one in three Ivorian respondents in the 2014 Afrobarometer survey said 'a lot'. Similarly, eight in ten respondents in 2014 believed voters were threatened with violence at election polls (Afrobarometer 2015). Given citizens' concern about potential electoral violence, then, it was logical that election observers saw peacefulness as a critical component in evaluating the 2015 election.

Observers emphasised the 'peacefulness' of the 2015 election in their observer assessments. In the first sentence of its media release on the election observation mission, the African Union called the Ivorian election (and the same-day elections in Tanzania) 'serene and peaceful'. The statement was brief and vague, but mentioned 'massive participation' and focused on peacefulness, calling on the electorate 'to remain calm, with the same serenity they demonstrated on the day of the voting' as votes were being counted and for stakeholders to use officially recognised 'peaceful' resolution mechanisms should any disputes arise (African Union Commission 2015).

A blog post issued on the National Democratic Institute web site discussing election observation began with 'A largely peaceful presidential election ...' (Staton 2015). At a media conference held three days after the election, POECI spokesperson Marie-Paule Kodjo congratulated the Ivorian people for a ' peaceful election' before sharing statistics about the POECI's observations (Abidjan.net 2015).

Of the three major groups watching the election, the ECOWAS observer mission was the only one not to begin its report with a discussion of peacefulness. Instead ECOWAS gave an overall positive assessment followed by an enumeration of the minor irregularities that occurred during the election (e.g. the late start to voting and difficulties in using biometric card readers). It was only halfway through its brief release that the ECOWAS mission mentioned 'peace in Côte d'Ivoire is crucial' (ECOWAS 2015).

To be sure, peacefulness is essential to the legitimacy and inclusivity of any election. But while a necessary condition, peacefulness is insufficient on its own in determining an election to be legitimate and inclusive. Furthermore, the lack of detailed observations on the election poses significant challenges to evaluating the veracity of the claim that the 2015 election was a 'democratic success' beyond its relative peacefulness. 


\section{VERIFYING OFFICIAL RESULTS AGAINST INDEPENDENT MEASURES AND EXPLORING REGIONAL PATTERNS}

The dominant performance by Ouattara in the 2015 election indicates less electoral competitiveness relative to 2010. On the one hand, if Ouattara was truly popular his dominance in the election should not be problematic for Côte d'Ivoire's democratic consolidation. On the other hand, if this lopsided victory was the result of fraud or due to a boycott by supporters of the opposition who questioned the legitimacy of the process, this would suggest some trouble with Côte d'Ivoire's march towards a consolidated democracy.

In this section we use two independent data sets to help verify official results. We find that the election results were largely in line with a parallel vote tabulation exercise conducted on election day and with a survey conducted over a year before the election. Both data sets indicate that the election was not only valid but should be perceived as valid by the public, which would strengthen its democratic legitimacy. Because there were calls by some groups to boycott, we also use a comparative analysis of voter turnout between 2010 and 2015 to analyse whether Ouattara's landslide victory in 2015 and the accompanying low turnout might have resulted from a boycott. If so, this would undermine the election's legitimacy.

One strategy to ensure the validity of an election, and to communicate this validity to the voting public, is to conduct a parallel vote tabulation (PVT). ${ }^{2}$ The PVT conducted by POECI largely confirmed the official results (POECI 2015b; Staton 2015). POECI estimated voter turnout at $53.1 \%$ with an accuracy of roughly $1.8 \%$. The official turnout reported by the CEI was close to the PVT and squarely in the margin of error, at $52.9 \%$. The PVT estimates for vote share similarly matched the official results. POECI estimated Ouattara won $83.5 \%$ of the vote and the official tally was $83.7 \%$, well within the approximately $1.9 \%$ margin of error. The PVT estimated that Ouattara's closest challenger, N'Guessan, would win $9.3 \%$ of the vote (with a roughly 1.5\% degree of accuracy) and the official tally reported by the CEI reported N'Guessan won 9.3\% (POECI 2015c). At the national level, at least, an independent and parallel count of the vote gives legitimacy to the results even if the incumbent's lopsided win might suggest less competitiveness.

Another method of assessing and communicating the validity of an election is to compare the official results with previous polling data. Afrobarometer ${ }^{3}$ fielded a survey in August-September 2014, over a year before the 2015 election

2 Also known as a quick count, PVT is an electoral observation methodology wherein results from a representative sample of polling stations are aggregated to verify overall results.

3 The Afrobarometer is a nonpartisan research network that conducts public opinion surveys on democracy, governance, economic conditions, and related issues in more than 30 countries in Africa. 
and before the creation of various political coalitions such as the anti-Ouattara National Coalition for Change (CNC).

When asked which party's candidate they would vote for as president if the election was held tomorrow, one third of Ivoirian respondents in the 2014 poll stated that either they would not vote, did not know who they would vote for, or refused to answer the question. This result suggested there would be low turnout. In the end turnout in the 2015 presidential election was 53\% (significantly less than the 2010 turnout of over $80 \%$, but much greater than the heavily boycotted elections of 1995 and 2000). The relatively low turnout may suggest apathy among voters, perhaps reflecting the widely held belief that the incumbent was likely to win, or perhaps reflecting a boycott by some in the opposition. Among the two thirds of Afrobarometer respondents who named a party, over $60 \%$ supported a party (including RDR and PDCI) that was a member of the RHDP, which supported Ouattara.

To assess whether opposition voters were boycotting the election, we matched constituency ('département') level data for the 2010 and 2015 elections from the CEI website and from abidjan.net. ${ }^{4}$ For each département we calculated the change in voter turnout between 2010 and 2015, and the vote share for Laurent Gbagbo (FPI), in the first round of the 2010 presidential election. If Gbagbo loyalists were boycotting the 2015 election we would expect to see a greater decline in voter turnout in the départements that more heavily favoured Gbagbo in 2010. Given Côte d'Ivoire's history of boycotts, the question of whether or not the opposition heavily boycotted the election is an important one for the legitimacy of Côte d'Ivoire's election and the effect that has on its democratic consolidation.

Figure 1 below shows the relationship between Gbagbo's 2010 vote share and the change in turnout for all of Côte d'Ivoire's départements. In most of the country turnout declined, but it declined less in districts that did not support Gbagbo in 2010 and it declined more in districts that did support Gbagbo. At first glance this might seem to suggest that a boycott had some effect among Gbagbo supporters. If a boycott was occurring, however, we would expect it to occur primarily in the region that supported Gbagbo.

Figure 2 below includes départements where Gbagbo won a majority of votes in 2010. In this scatter plot it is clear that the constituencies where Gbagbo was most popular had a change in turnout similar in scale (and perhaps slightly smaller), compared with constituencies where Gbagbo was the moderate favourite in 2010. Our interpretation is that the boycott was not a major cause of the low turnout in the 2015 election relative to 2010, and therefore not a major cause of

4 There were 90 départements in 2010, but since then many have been subdivided, leading to over 100 départements for the 2015 election. We did not attempt to match new départements, so we have a total of 87 matched départements, which accounts for 86 percent of the total of 2015 votes. 


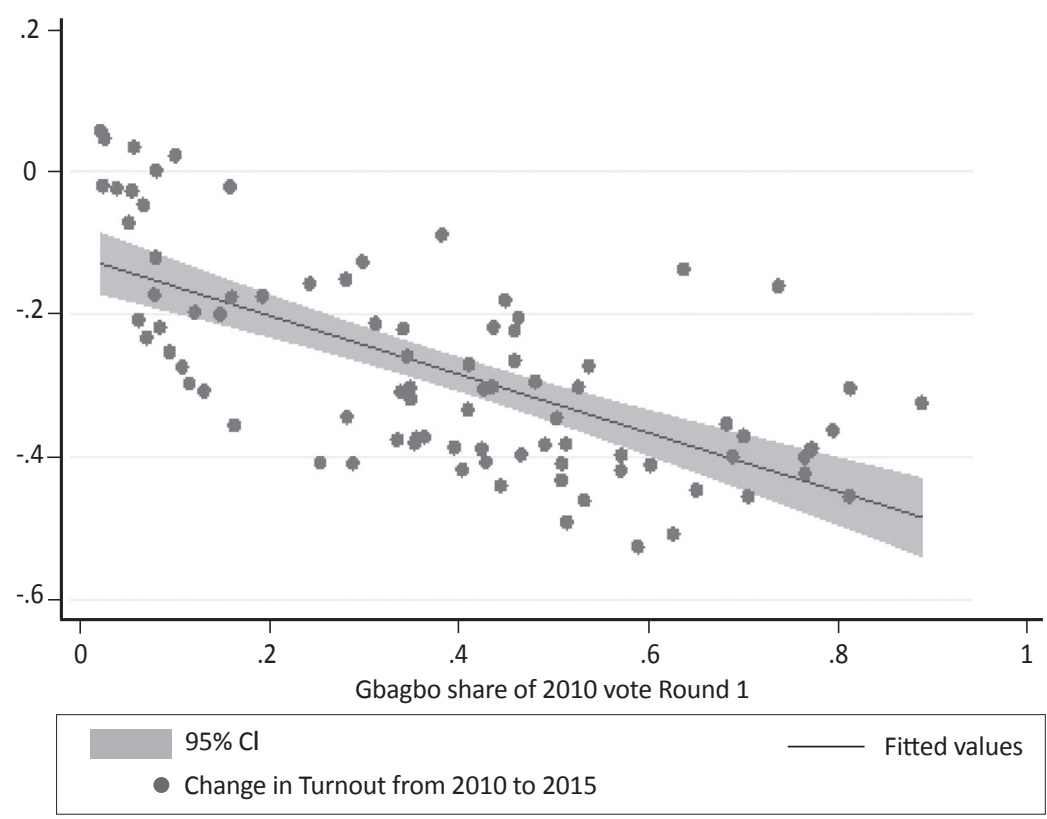

Figure 1: Scatterplot of change in turnout from 2010 to 2015 and Gbagbo (FPI) first-round presidential vote share in 2010 (all départements).

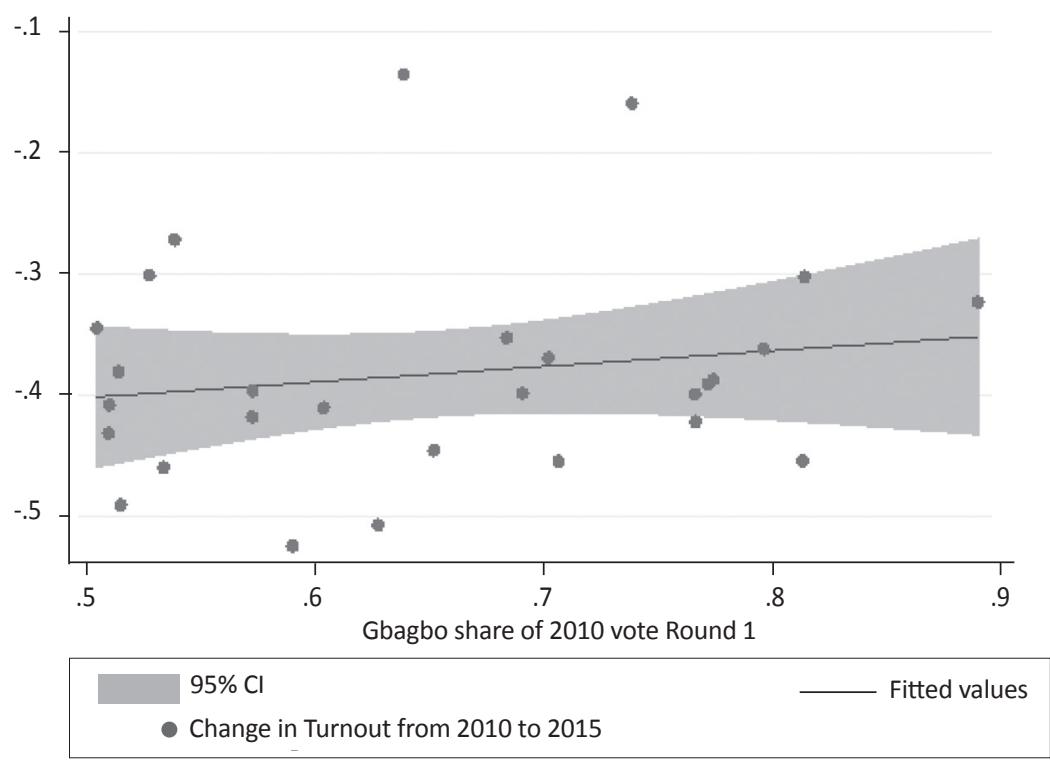

Figure 2: Scatterplot of change in turnout from 2010 to 2015 and Gbagbo (FPI) first-round presidential vote share in 2010 (départements won by Gbagbo in 2010). 
Ouattara's landslide victory. Instead we believe the causality goes in the other direction - the election was unlikely to be competitive because the economy was doing well and Ouattara was widely expected to win. Therefore, as is the case in elections throughout the world (Blais 2006), an uncompetitive election generally attracted relatively few voters, and the voters who favoured the predicted winner were more motivated to vote than voters who preferred the likely loser.

In the 2010 presidential election Ouattara was particularly popular in the north, Gbagbo was most popular in the south, and Bédié's highest support was in the centre of the country (Bassett 2011). In the 2015 election Ouattara received a majority in nearly every region, with high support in northern regions such as Poro and Tchologo (98\% each). Ouattara also received strong support in many southern regions such as Abidjan, where he won over $80 \%$ of the vote (Commission Electorale Independante 2015). Even in FPI strongholds such as Me Region in the southeast, Ouattara received a plurality (45\% versus $29 \%$ for N'Guessan).

\section{CONCLUSION}

The 2015 presidential election in Côte d'Ivoire was the first since multiparty elections were introduced in 1990 in which all major parties were able to compete, and civil war was not triggered. It appears at first glance that this was a step forward in the democratic consolidation of the country. In this paper we studied the extent of democratic progress registered by this milestone election. In particular we focused on the three democratic qualities of elections laid out by Lindberg (2006): competition, participation and legitimacy.

The incumbent, Ouattara, won the 2015 election by a landslide, with $83.7 \%$ of the vote, which on the surface might appear to be a decrease in the level of competition compared to 2010, when the decision was made with little over $50 \%$ in a runoff election. We believe, however, that this landslide was the result primarily of a booming economy and a broad political coalition rather than restrictive electoral institutions, as was the case in Côte d'Ivoire during the single-party era and the first several multi-party elections, most of which were boycotted by major opposition parties. The outcome was not competitive, but conditions were present that enabled competition. If one considers that the 2010 election was the first in which an incumbent was defeated in a presidential election and that Ouattara, because of his age, is unlikely to attempt a third term, there is reason for hope that future elections in Côte d'Ivoire will continue to increase in competitiveness relative to the pre-2010 period.

With regard to participation, voter turnout in 2015 also declined relative to 2010. Whereas more than 4 million voters participated in the 2010 election, only 3.3 million participated in the 2015 election. The winner's vote count in 2015 was 
higher, though, than in any election prior to 2010 and we believe the low turnout resulted from high certainty of the outcome, more attributable to incumbent advantages in a booming economy than to more troubling explanations such as voter suppression or boycotts.

The greatest step forward democratically was the legitimacy of the 2015 election. In contrast to the unrest that Côte d'Ivoire experienced during or after previous elections, the 2015 presidential election was 'peaceful and largely smooth' (Kouadio and Corey-Boulet 2015). Following the 2010 presidential election, tainted by the initial refusal of the incumbent to accept the results, the peaceful conclusion of the election of October 2015 was an important step towards consolidation of democracy in Côte d'Ivoire.

Although the 2015 elections were peaceful, issues underpinning the social turmoil that led to conflict in the recent past - namely land grievances and identity politics - have not yet been addressed meaningfully and continue to pose challenges to Côte d'Ivoire's democratic development (Klaus and Mitchell 2015; Whitaker 2015). Tests for Côte d'Ivoire's democratic consolidation continue into the future, when election years might occur during years of economic decline or stagnation, which would create a starker trade-off for incumbents between electoral defeat and free and fair elections.

\section{ACKNOWLEDGEMENTS}

We thank two anonymous reviewers and the editors of the Journal of African Elections for their helpful feedback.

\section{REFERENCES}

Abidjan.net 2015, 'La POECI félicite le peuple ivoirien pour « l'élection apaisée »' 29 October. Available at: http: / / news.abidjan.net/h/572257.html

Africa Confidential 2015a, 'Côte d'Ivoire: the election gets messier', Africa Confidential, vol. 56, no. 12, p. 8.

Africa Confidential 2015b, 'Côte d'Ivoire: Ouattara walks it', Africa Confidential, vol. 56, no. 22, p. 4.

African Elections Database 2012, 'Elections in Côte d'Ivoire', African Elections Database. Available at: http: / / africanelections.tripod.com/ci.html

African Union Commission 2015, 'AU Commission chairperson congratulates Côte d'Ivoire and Tanzania for conducting peaceful general elections', Addis Ababa: African Union Commission. Available at: http: / / www.african-union. africa-newsroom.com/ press / au-commission-chairperson-congratulatescote-divoire-and-tanzania-for-conducting-peaceful-general-elections 
Afrobarometer 2015, 'Round 6: Côte d'Ivoire', Afrobarometer. Available at: http:/ / www.afrobarometer.org

Bah, A 2010, 'Democracy and civil war: citizenship and peacemaking in Côte d'Ivoire', African Affairs, vol. 109, no. 437, pp. 597-613.

Bassett, T 2011, 'Winning coalition, sore loser: Côte d'Ivoire's 2010 presidential elections', African Affairs, vol. 110, no. 440, pp. 469-479.

Bath, I 2015, 'Présidentielles 2015/Mamadou Koulibaly: "Notre Commission électorale ne respecte aucun critère d'indépendance",' Linfodrome, Available at : http: / / www.linfodrome.com/vie-politique/19449-presidentielles-2015mamadou-koulibaly-notre-commission-electorale-ne-respecte-aucun-critered-independance

Bavier, J 2015, 'Ex-president's backers in power struggle before Ivory Coast polls', Reuters, 2 September.

Blais, A 2006, 'What affects voter turnout?', Annual Review of Political Science, vol. 9, pp. 111-125.

Brice, M 2015, 'Ivory Coast opposition calls for new electoral commission', Reuters, 28 September.

Carter Center 2012, 'International election observation mission to Côte d'Ivoire', The Carter Center, Atlanta.

Cheeseman, N 2010, 'African elections as vehicles for change', Journal of Democracy, vol. 21, no. 4, pp.139-153.

Commission Electorale Independante 2015, 'Presidential election results', Available at: https: / / www.cei-ci.org/

Daddieh, CK 2001, 'Elections and ethnic violence in Côte d'Ivoire: the unfinished business of succession and democratic transition', African Issues, vol. 29, no. 1/2, pp. 14-19.

Dahl, R 1975, Polyarchy: participation and opposition. Yale University Press, New Haven and London.

Economist Intelligence Unit 2015a, 'Country report 3rd quarter 2015: Côte d'Ivoire', Economist Intelligence Unit, London.

Economist Intelligence Unit 2015b, 'Pre-election clashes erupt in opposition strongholds', Economist Intelligence Unit Election Watch, 16 September.

ECOWAS 2015, 'The Ivorian presidential election of 25 October 2015 was conducted in a calm and peaceful atmosphere', ECOWAS, 27 October. Available at: http: / / www.ecowas.int/ the-ivorian-presidential-election-of-25-october2015-was-conducted-in-a-calm-and-peaceful-atmosphere/

Fick, M 2015, 'Coming years will be critical test of Ivory Coast's focus', Financial Times, 27 September.

Flynn, D 2015, 'Ivorian opposition coalition threatens to obstruct elections', Reuters 31 August. 
Fort, P \& Koffi, C 2015, ‘Opposition contests turnout in Ivory Coast presidential vote', Agence France-Presse 26 October.

Human Rights Watch 2011, 'They killed them like it was nothing': the need for justice for Côte d'Ivoire's post-election crimes, Human Rights Watch, New York.

Human Rights Watch 2015, 'Côte d'Ivoire: respect rights during elections', Human Rights Watch 21 October. Available at: https://www.hrw.org/ news / 2015/10/21/ cote-divoire-respect-rights-during-elections

Huntington, S 1993, The third wave: democratization in the late twentieth century, University of Oklahoma Press, Norman.

Kimou, A \& Kouyaté, P 2015, ‘The Ivoirian Independent Electoral Commission and challenges for the 2015 presidential election', West Africa Insight.

Klaus, K \& Mitchell, M 2015, 'Land grievances and the mobilisation of electoral violence: evidence from Côte d'Ivoire and Kenya', Journal of Peace Research, vol. 52, no. 5, pp. 622-635.

Kouadio, I \& Corey-Boulet, R 2015, 'Ivory Coast President Ouattara easily wins re-election', Associated Press, 28 October.

Lansford, T 2015, Political handbook of the world 2015, CQ Press, Thousand Oaks.

Lindberg, S 2006, Democracy and elections in Africa, The Johns Hopkins University Press, Baltimore.

Ngotta, S 2015, 'Observation de la revision de la liste electorale: Affluence en legere hausse dans les centres de recensement et prolongation de la periode de la liste electorale', Newsletter POECI. Available at: http: / / poeci-elections.org/ observation-de-la-revision-de-la-liste-electorale-affluence-en-legere-haussedans-les-centres-de-recensement-et-prolongation-de-la-periode-de-revisionde-la-liste-electorale/

Niakate, H 2015, 'Côte d'Ivoire elections: on the campaign trail', The Africa Report, 17 October.

Nugent, P 2004, Africa since independence: a comparative history, Palgrave Macmillan, New York.

Piccolino, G 2012, 'David against Goliath in Côte d'Ivoire? Laurent Gbagbo's war against global governance', African Affairs, vol. 111 no. 442, pp. 1-23.

Piccolino, G 2014, 'Ultranationalism, democracy and the law: insights from Côte d'Ivoire', Journal of Modern African Studies, vol. 52, no. 1, pp. 45-68.

POECI 2015a, 'Déclaration préliminaire: election présidentielle s'est bien déroulée malgré des retards quant à l'ouverture des bureaux de vote', POECI, 26 October. Available at: http: / / poeci-elections.org/declaration-preliminaireelection-presidentielle-sest-bien-deroulee-malgre-des-retards-quant-alouverture-des-bureaux-de-vote/

POECI 2015b, 'Communiqué de presse: La POECI estime que le taux de participation serait de 53,0\% avec un degré de precision de plus ou moins 1,8\%', POECI, 26 October. 
POECI 2015c, 'Tendances dégagées par l'observation PVT réalisée par la POECI', POECI, 28 October. Available at: http:// poeci-elections.org/tendancesdegagees-par-lobservation-pvt-realisee-par-la-poeci/

Przeworski, A, Alvarez, ME, Cheibub, JA \& Limongi, F 2000, Democracy and development: political institutions and well-being in the world, 1950-1990, Cambridge University Press, New York.

Riedl, R \& Dickovick, JT 2014, 'Party systems and decentralization in Africa', Studies in Comparative International Development vol. 49, pp. 321-342.

Staton, B 2015, 'Successful observation of Côte d'Ivoire election builds credibility of civil society', DemocracyWorks, National Democratic Institute, 13 November. Available at: https:/ / www.demworks.org/ successful-observation-c-te-divoire-election-builds-credibility-civil-society

Théroux-Bénoni, LA, Abatan, E \& Kobi, J 2015, ‘Côte d'Ivoire presidential election: what's at stake for stability?', Institute for Security Studies. Available at: https: / / www.issafrica.org/iss-today / cote-divoire-presidential-electionwhats-at-stake-for-stability

United Nations Security Council 2015, Thirty-seventh progress report of the SecretaryGeneral on the United Nations Operation in Côte d'Ivoire. S/2015/940.

Wantchekon, L 2003, 'Clientelism and voting behavior: evidence from a field experiment in Benin', World Politics, vol. 55, pp. 399-422.

Whitaker, BE 2005, 'Citizens and foreigners: democratization and the politics of exclusion in Africa', African Studies Review, vol. 48, no.1, pp. 109-26.

Whitaker, BE 2015, 'Playing the immigration card: the politics of exclusion in Côte d'Ivoire and Ghana', Commonwealth \& Comparative Politics, vol. 53, no. 3, pp. 274-293. 